\title{
Combination of extracts from Aristolochia cymbifera with streptomycin as a potential antibacterial drug
}

Willer F Silva Jr', Samyra G Cecílio ${ }^{2}$, Cintia LB Magalhães ${ }^{3 \dagger}$, Jaqueline MS Ferreira ${ }^{4 \dagger}$, Antonio H Tótola ${ }^{5+}$ and Jose $C$ de Magalhaes ${ }^{5^{*}}$

\begin{abstract}
The appearance of new antibiotic-resistant bacteria is a societal problem that requires the development of new alternative treatments. Therefore, this work evaluated the antibacterial activity of ethanolic (EHI), dichloromethanic (EDI) and hexanic (EHE) extracts from Aristolochia cymbifera stems and the combination of these extracts with an antimicrobial drug to develop a new antibacterial therapy. The EDI, EHE and EHI extracts were obtained by maceration using three different solvents. The minimal inhibitory concentrations (MIC) of these extracts were determined using the microdilution test to determine the antibacterial potential of these extracts and their combination with streptomycin against Staphylococcus aureus, Bacillus cereus, Klebsiella pneumoniae and Shigella flexneri. The extract dose leading to the cytotoxicity of 50\% of the cells (CC50) was evaluated using mammalian cells MA104 and the 3-(4,5-dimethylthiazol-2-yl)-2,5-diphenyltetrazolium bromide (MTT) colorimetric assay. The extracts had a MIC under $500 \mathrm{mg} / \mathrm{L}$ and a CC50 lower than $50 \mathrm{mg} / \mathrm{L}$. The antibiotic/extract proportion influenced the antibacterial activity of the mixtures, and the proportion that optimized the antibacterial activity of streptomycin was a mixture that contained 75 percent of extract. This composition included less than $6.5 \mathrm{mg} / \mathrm{L}$ of extract and $2.5 \mathrm{mg} / \mathrm{L}$ of streptomycin and has potential as a new antibacterial therapy.
\end{abstract}

Keywords: Aristolochia cymbifera; Antibacterial activity; Synergism; Cytotoxicity; Drug discovery; Natural products

\section{Background}

Longstanding experiments and the popular use of plants as therapeutic tools have helped to introduce chemical entities in modern medicine. Plants, especially those with ethnopharmacological uses, have been the main sources for the discovery of new drugs. Worldwide, natural products have played a prominent role in the prevention and treatment of several diseases for thousands of years (Chin et al. 2006).

Drugs based on natural products have been developed from sources that include terrestrial plants, microorganisms, marine organisms, terrestrial vertebrates and invertebrates (Newman et al. 2000). Brazil has a vast forest and a

\footnotetext{
*Correspondence: josecarlos@ufsj.edu.br

${ }^{\dagger}$ Equal contributors

${ }^{5}$ Departamento de Química, Biotecnologia e Engenharia de Bioprocessos (DQBIO), Universidade Federal de São João Del-Rei, Campus Alto Paraopeba, Rodovia MG 443, Km 07, Congonhas/Ouro Branco, Ouro Branco, Minas Gerais CEP 36420-000, Brazil

Full list of author information is available at the end of the article
}

popular tradition associated with the use of medicinal plants for antimicrobial applications (Sartoratto et al. 2004). Thus, extracts from plants can be used as sources of new drugs or antimicrobial compounds (Alviano and Alviano 2009) and these new therapies are of great importance, as the emergence of resistant strains has increased the difficulty of treating infections (Cole et al. 2003).

Staphylococcus aureus (S. aureus), Bacillus cereus (B. cereus), Klebsiella pneumoniae (K. pneumoniae) and Shigella flexneri (S. flexneri) are known to cause enteric disease. Shigella flexneri causes enteric shigellosis and is responsible for 1.1 million deaths per year, with children being the most affected group (Jennison and Verma 2004). B. cereus is responsible for diarrheal food poisoning due to its toxin production (Ceuppens et al. 2012). Staphylococcus aureus can induce many diseases, such as bovine mastitis, skin disease and gastroenteritis, due to the ingestion of enterotoxins (Reinhardt et al. 2013; Moran et al. 2013; Hyeon et al. 2013) and

\section{实}

(C) 2013 Silva et al.; licensee Springer. This is an Open Access article distributed under the terms of the Creative Commons Attribution License (http://creativecommons.org/licenses/by/2.0), which permits unrestricted use, distribution, and reproduction in any medium, provided the original work is properly cited. 
are often associated with antibiotic resistance. Another species that has been shown to be antibiotic resistant is Klebsiella pneumoniae, including carbapenem-resistant Klebsiella pneumoniae (CRKP) (Tenover 2006), which can inactivate the carbapenems.

In some regions, enteric diseases are treated with teas, infusions or macerated medicinal plants and this folk medical knowledge is transmitted from generation to generation. This alternative treatment, which sometimes represents the only therapy option for many people, is widely used due to its low cost and easy access (Veiga et al. 2005).

Species of the Aristolochia genus are used in traditional medicine, mainly in South America, to treat skin diseases, poisoning, wounds, worms, diarrhea, and also as emmenagogues. The species Aristolochia cymbifera (Aristolochiaceae) is popularly known as jarrinha, papo de peru, cipó mil homens, cassaú and other common names (Wu et al. 2004). Some studies using A. cymbifera extracts have indicated potential antimicrobial properties of this species. In experiments performed by Carvalho et al. (2008), the leaf methanol extract of this species showed strong activity against promastigotes from Leishmania chagasi, and the diterpene copalic acid was isolated using bioassay-guided fractionation and showed high toxicity against the extracellular form of the parasite. Sartorelli et al. (2010) observed that copalic acid was also active against trypomastigotes of Trypanosoma cruzi. Copalic acid maintained its selectivity against $T$. cruzi, although it showed low toxicity against infected mammalian cells.

In studies conducted by Alviano et al. (2008) that evaluated the antioxidant potential and antimicrobial properties of plants used in Brazilian folk medicine, the crude ethanol-water (1:1) extract from A. cymbifera stems exhibited a significant antibacterial effect. This extract inhibited the growth of the oral bacteria Prevotella intermedia, Porphyromonas gingivalis, Fusobacterium nucleatum, Lactobacillus casei and Streptococcus mutans even in the presence of an artificial biofilm. In experiments using the agar dilution method, the ethanolic extract from A. cymbifera stems inhibited the growth of various staphylococci, including multi-drug resistant endemic Brazilian clones of Staphylococcus aureus. The hexane fraction of the extract proved to be active against Pseudomonas aeruginosa strains (Machado et al. 2005).

Thus, based on the potential and promising use of medicinal plants in traditional medicine, the current investigation involved screening the ethanolic (EHI), dichloromethanic (EDI) and hexanic (EHE) extracts of $A$. cymbifera against important pathogenic bacteria and combining these extracts with streptomycin determine the prospects for a new antibacterial therapy.

\section{Results and discussion \\ Results}

\section{Extract absorption outlines}

The three extracts from $A$. cymbifera had differences in their absorption spectra, mainly in the UV region (Figure 1). In the EHE and EDI extracts, the most intense absorption bands were observed at $300 \pm 2$ and $303 \pm 3 \mathrm{~nm}$, respectively. The absorbance of EHE at these wavelengths was lower than that of EDI. An absorption band at $400 \mathrm{~nm}$ was also observed in EHI and EDI.

\section{Determination of Minimum Inhibitory Concentration (MIC)}

The MIC values found for the three extracts are presented in Table 1. Values less than or equal to $500 \mathrm{mg} \mathrm{L}^{-1}$ were considered to be the MIC. A MIC of less than or equal to $100 \mathrm{mg} \mathrm{L}^{-1}$ was considered as potential for prospect a new therapy (Rios and Recio 2005). B. cereus appeared to be the most sensitive bacteria to these three extracts, with a MIC lower than $100 \mathrm{mg} \mathrm{L}^{-1}$. The hydrophilic extracts (EDI and EHI) were more active against $S$. aureus and S. flexneri than was the hydrophobic hexanic extract (EHE).

\section{Effect of combination of streptomycin and A. cymbifera extracts}

Different effects were observed when the streptomycin/extract proportions were changed, and an increase in the antibacterial activity was observed when the percentage of extracts in the mixture was higher (see Additional file 1). A mixture containing $75 \%$ extract reduced the MIC value of streptomycin approximately four-fold against $S$. aureus, K. pneumoniae, B. cereus and S. flexneri.

The synergistic effect of the extract and the drug and the variation in antibacterial activity induced by the different streptomycin/extract mixtures were demonstrated by interaction index curves established for each tested bacteria (Figure 2).

The maximum antibacterial activity was obtained in mixtures containing $25 \%$ of streptomycin. There were differences in interaction index (II) between the extracts when used against S. aureus and B. cereus (Figures 2a and $2 b$ ). The best II values were observed for EHE when used against $B$. cereus, which was the most susceptible bacteria to the streptomycin/extract mixture.

\section{Evaluation of cytotoxicity in mammalian cells}

The results obtained in the in vitro cytotoxicity assays were plotted in terms of the percentage of living cells versus the concentration of the extract (Figure 3). A non-linear regression was generated to obtain an equation that demonstrates the relationship between the two variables. Adequate correlation coefficients $\left(R^{2}\right.$ of approximately 1.0 ) were obtained, indicating the efficiency of adopted models to estimate the CC50 (Figure 3). The 


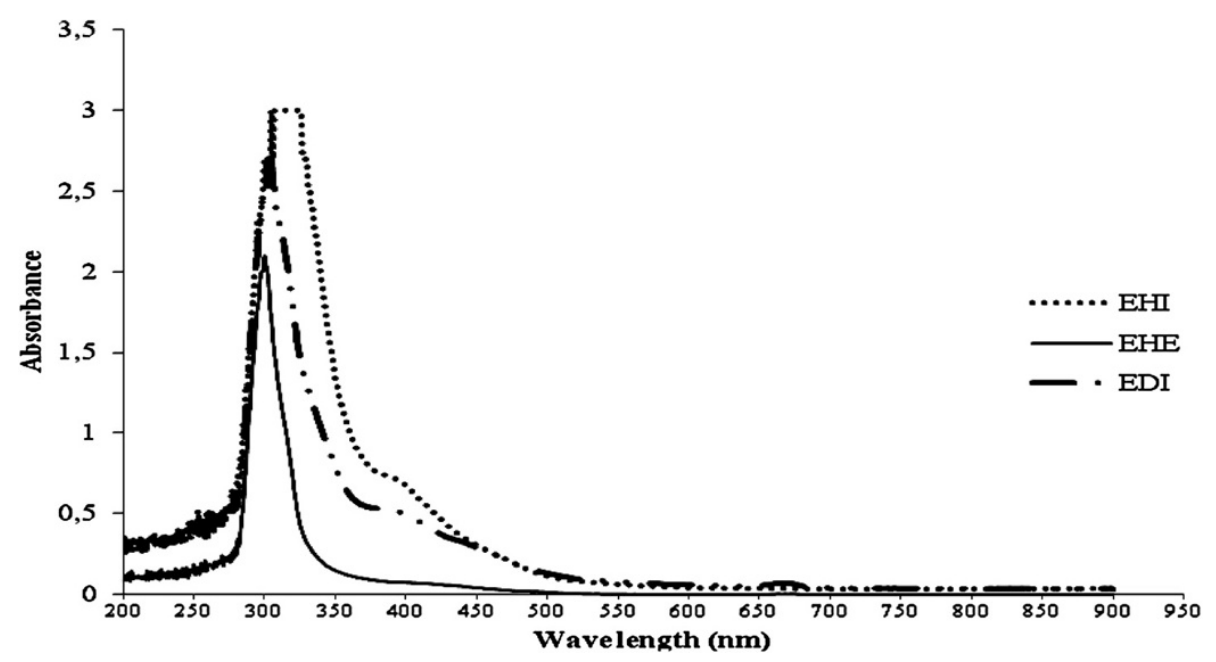

Figure 1 UV/Vis absorption spectra (200 to $900 \mathrm{~nm}$ ) of EDI, EHE and EHI. EHE showed the smallest absorption band at $316 \pm 6 \mathrm{~nm}$. EDI and EHI had similar profiles and showed an absorption band at $400 \mathrm{~nm}$ that was not observed in the EHE spectrum.

hexanic extract was the least toxic with $\mathrm{CC50}=$ $40.75 \mathrm{mg} \mathrm{L}^{-1}$.

\section{Discussion}

The MIC results were significant with the exception of EHE against $S$. aureus, mainly because of the antibacterial activity against $S$. aureus and $K$. pneumoniae, which have shown resistance to several antibacterial drugs (AlMasaudil et al. 1991; Mangeney et al. 2000). The low MIC values of the extracts against $B$. cereus indicate that the three extracts should be further studied to find active compounds to design new drugs. There were differences in antibacterial activity against $S$. aureus, $S$. flexneri and $K$. pneumoniae based on both extract polarity and bacterial strain. This fact can be associated with physiological differences between the microorganisms and the diversity and amounts of compounds in each extract.

The EHE and EDI extracts contain compounds with similar absorption bands in the UV region, but with

Table 1 Minimum inhibitory concentration $\left(\mathrm{mg} \mathrm{L}^{-1}\right)$ of ethanolic (EHE), dichloromethanic (EDI) and hexanic (EHE) extracts from Aristolochia cymbifera

\begin{tabular}{|c|c|c|c|c|c|c|}
\hline \multirow[t]{3}{*}{ Bacteria } & \multicolumn{6}{|c|}{ Extracts from Aristolochia cymbifera } \\
\hline & \multicolumn{2}{|c|}{ EDI } & \multicolumn{2}{|c|}{ EHE } & \multicolumn{2}{|c|}{$\mathrm{EHI}$} \\
\hline & $\mathrm{X}^{*}$ & SD † & $\mathrm{X}^{*}$ & SD † & $\mathrm{X}^{*}$ & SD † \\
\hline S. aureus & 214.29 & 60.99 & $>500$ & $>500$ & 160.71 & 60.99 \\
\hline B. cereus & 89.29 & 33.41 & 62.50 & 0.00 & 62.50 & 0.00 \\
\hline K. pneumoniae & 416.67 & 129.10 & 250.00 & 0.00 & 500.00 & 0.00 \\
\hline S. flexneri & 166.67 & 64.55 & 395.83 & 166.15 & 200.00 & 68.47 \\
\hline
\end{tabular}

${ }^{*} X$, Average MIC values obtained from replicates.

$+\mathrm{SD}$, standard deviation associated with the average obtained from the replicates. different intensities. In the spectra of EHI and EDI, an absorption band at $400 \mathrm{~nm}$ was observed that was not found in the EHE spectrum (Figure 1). These data indicated that the use of solvents with different polarities allowed the extraction of distinct constituents in different concentrations. Some compounds have been isolated from Aristolochia cymbifera extracts, including 2oxopopulifolic acid (Machado et al. 2005), copalic acid, fargesin, hinokinin, kusunokinin, sesamin, epieudesmin, benznidazole (Sartorelli et al. 2010), (5R,8R,9S,10R)-ent3-cleroden-15-oic acid (Leitão et al. 1992), (5R,8R, 9S,10S)-ent-labd-14-en-8ß-ol (Lopes et al. 1988), and (-)-kolavelool (Lopes et al. 1987).

The highest concentrations of EDI, EHE and EHI in the streptomycin/extract mixture that showed a synergistic effect were $10.42 \pm 3.61 \mathrm{mg} \mathrm{L}^{-1}$ (50\% EDI), $6.25 \pm$ $2.71 \mathrm{mg} \mathrm{L}^{-1}$ (75\% EHE) and $6.25 \pm 2.71 \mathrm{mg} \mathrm{L}^{-1}(75 \%$ EHI) against K. pneumonia (Additional file 1). Using the non-linear regression equations obtained from the cytotoxicity assay (Figure 3), the percentage of living cells at the above extract concentrations would be $68.00 \pm$ $11.93,122.54 \pm 0.29$ and $80.49 \pm 10.77$ respectively, each of which resulted in more than $50 \%$ living cells.

The in vitro toxic effect of Aristolochia cymbifera extracts on MA104 cells (Figure 3) is similar to that observed in studies that report high toxicity of the Aristolochia genus to human kidney cells, which was associated with aristolochic acids (Chen et al. 2010). However, the checkerboard dilution test used in this study showed that lower extract concentrations improve the antibacterial activity of the mixture (see Additional file 1).

The 75\% EHE mixture was generally the most effective solution against the studied bacteria (Additional file 1), containing a streptomycin concentration near the MIC 


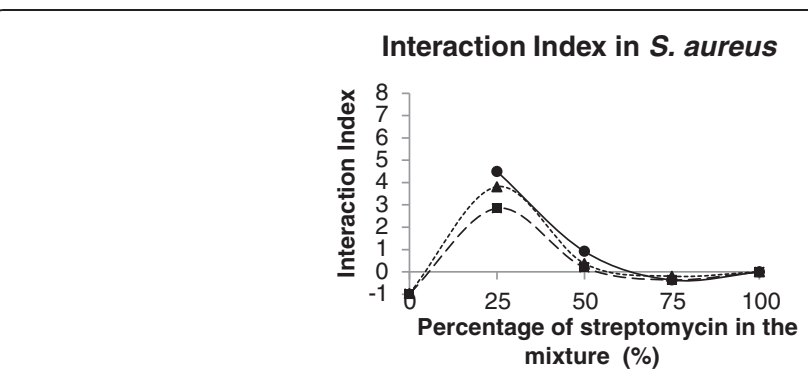

(a)

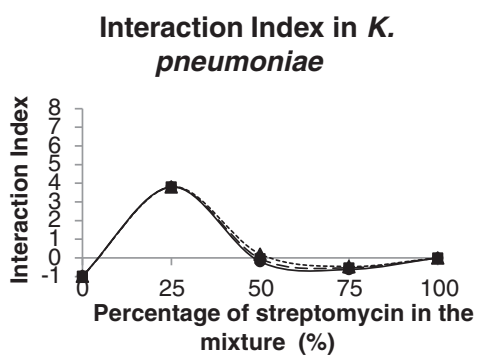

(c)
Interaction Index in B. cereus

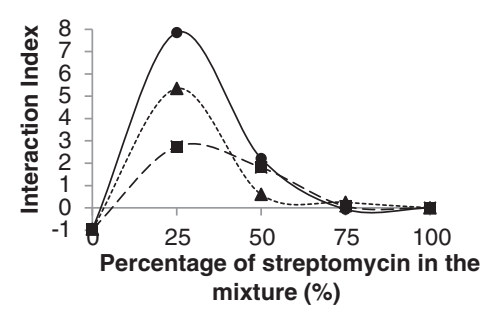

(b)

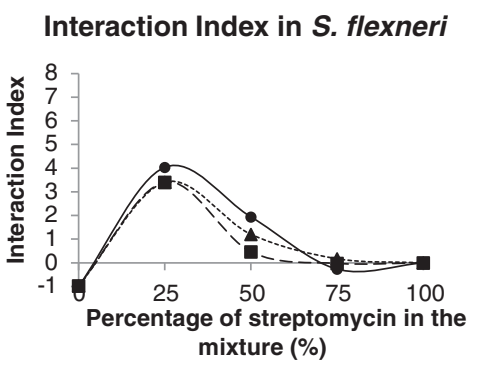

(d)

Figure 2 Interaction indexes (II) of the EDI $(\square)$, EHE $(\bullet)$ and EHI $(\boldsymbol{\Delta})$ extracts as a function of the percentage of streptomycin in the mixture for S. aureus (a), B. cereus (b), K. pneumoniae (c) and S. flexneri (d). The optimum proportion of the mixture was $75 \%$ extract (II maximum). There was a large difference in the II of EHE between the B. cereus and the other bacteria. There was no difference in the extracts with regard to the antibacterial activity of streptomycin against $K$. pneumoniae.

of the antibiotics recommended for the treatment of S. aureus (oxacillin $0.5 \mathrm{mg} \mathrm{L}^{-1}$ ) (Auwaerter et al. 2013; European Committee on Antimicrobial Susceptibility Testing 2013) and B. cereus (ciprofloxacin $0.25 \mathrm{mg} \mathrm{L}^{-1}$ ) (Turnbull et al. 2004). Based on these data and in vivo cytotoxicity tests, which must be performed, the mixture of streptomycin plus the hexanic extract from Aristolochia cymbifera has good potential to be used as an alternative treatment against the studied bacteria. Even if the toxic effects of $A$. cymbifera are related to the aristolochic acids, this damage is associated with high cumulative doses of these compounds (Nortier et al. 2000; Martinez et al. 2002), which are unlikely to occur with the low extract concentration in the streptomycin/extract mixture that demonstrated antibacterial activity in this study. Additionally, the use of A. cymbifera extracts in addition to antibiotic drugs reduces the dose of streptomycin required for treatment, which can decrease the resistance of

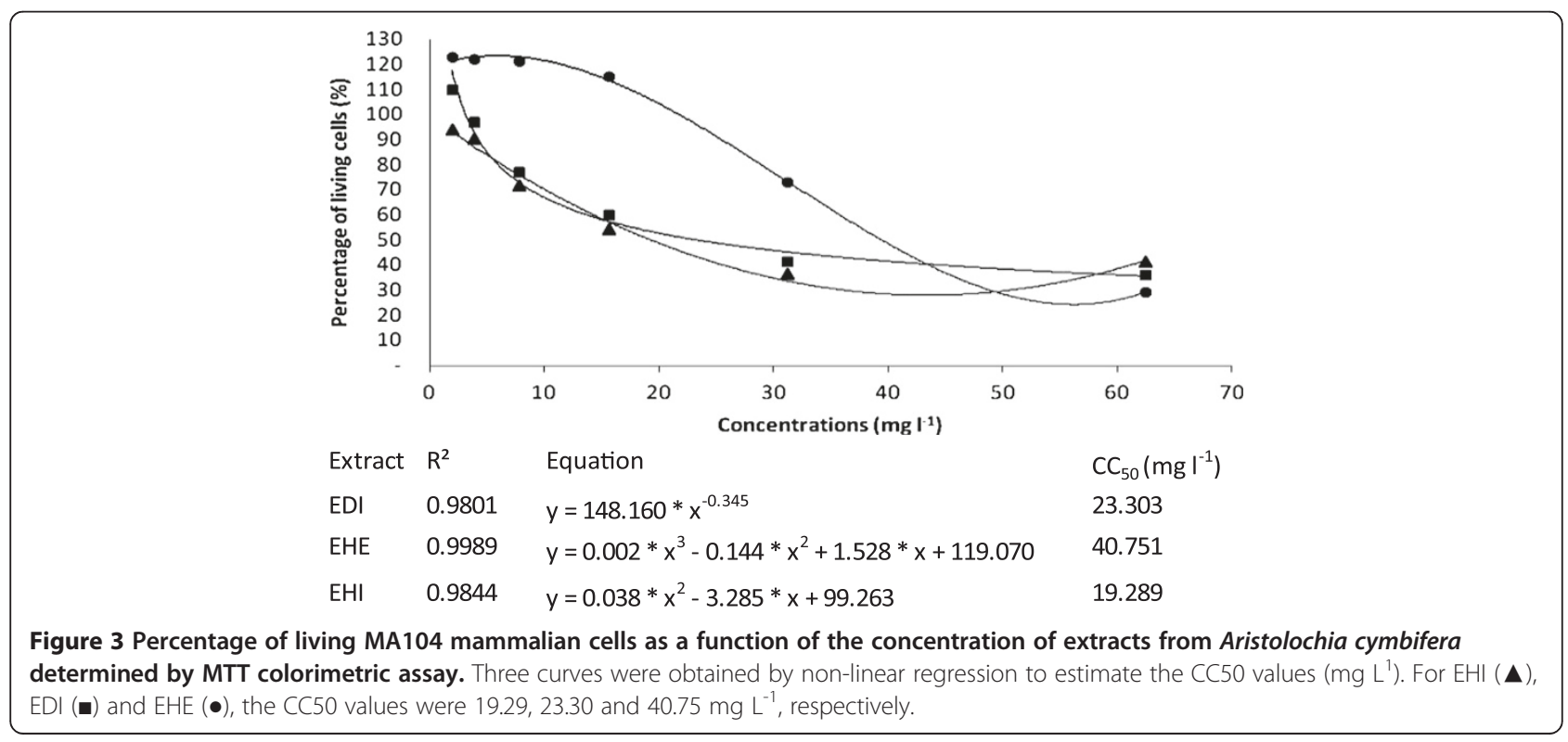


bacteria to the antibiotic and reduce the costs of antibiotic therapy.

Streptomycin is an aminoglycoside antibiotic that acts on the $30 \mathrm{~S}$ subunit of the bacterial ribosome and prevents protein synthesis, causing bacterial death (Luzzatto et al. 1968). Thus, one possible hypothesis for the synergic effect between streptomycin and A. cymbifera extracts may be that compounds that are present in the extracts increase membrane fluidity or permeability, helping the streptomycin molecules cross the bacterial membrane to enter the cytoplasm. Some compounds identified in A. cymbifera, such as copalic acid, have been shown to be able to disrupt the cell membrane (Souza et al. 2011).

\section{Conclusion}

The popular use of medicinal plants can sometimes be a good indicator of a new product source, as plants have several substances with different proprieties that can cause a specific biological effect. In this study, the antibacterial activity of ethanolic, hexanic and dichloromethane extracts form A. cymbifera stems was studied in addition to the antibacterial activity of streptomycin/extract mixtures. The cytotoxicity of the extracts on mammalian cells was also evaluated.

The results show that $A$. cymbifera extracts have compounds with potential as antibacterial drugs against $S$. aureus, $K$. pneumoniae, B. cereus and S. flexneri. The antibiotic/extract proportion affected the antibacterial activity of the mixture and the proportion that optimized the streptomycin's antibacterial activity contained 75 percent extract. At this percentage, the streptomycin's activity was increased four-fold.

Although the three extracts were toxic to the mammalian cells, at the concentrations used in the 75 percent extract they were less toxic. Thus, to demonstrate the safety of the use of a mixture of streptomycin/A. cymbifera extracts and the mode of action of these extracts when combined with streptomycin, in vitro and in vivo toxicity assays should be performed in addition to mechanistic studies.

\section{Methods}

\section{Plant extract preparation}

Stem samples from A. cymbifera (Mart. \& Zucc) were purchased from Nutri Comércio de Ervas Ltda. Company (São Paulo, Brazil) (Lot: MIH0111DM). Extracts were obtained by maceration using $50 \mathrm{~g}$ of the stems in ethanol, dichloromethane or hexane for three weeks $(5 \times$ $250 \mathrm{~mL}$ of each solvent). The mixtures were filtered and the solvents were removed under reduced pressure in a rotary evaporator at $45^{\circ} \mathrm{C}$. The crude extracts (EDI= $1.15 \mathrm{~g}, \mathrm{EHE}=0.27 \mathrm{~g}$ and $\mathrm{EHI}=3.38 \mathrm{~g}$ ) were dissolved in DMSO and stored at $-20^{\circ} \mathrm{C}$. The extracts were analyzed to determine their absorption spectrum over a range of wavelengths between 200 and $900 \mathrm{~nm}$.

\section{Microorganisms}

Reference bacterial strains were chosen in accordance with their ability to cause enteric disorders or association with gastrointestinal disorders or food poisoning episodes as follows: Staphylococcus aureus (ATCC 29213), Bacillus cereus (ATCC 11778), Klebsiella pneumoniae (ATCC 4352) and Shigella flexneri (ATCC 12022). The bacteria were reactivated on nutrient agar plates.

\section{Determination of Minimum Inhibitory Concentration (MIC)}

The MIC was determined using a microdilution assay in a 96-well microplate, as suggested by National Committee for Clinical Laboratory Standards (NCCLS 2003), with modifications. The inoculum was adjusted to 0.5 on McFarland's scale and diluted to $10^{6} \mathrm{CFU} \mathrm{mL}^{-1}$ in nutrient broth (HiMedia Laboratories ${ }^{\circ}$, India), which was used as the growth medium. The initial concentration of the extracts was $500 \mathrm{mg} \mathrm{L}^{-1}$, which was decreased 50 percent for each subsequent microplate's column. Streptomycin (Estreptomax ${ }^{\circ}$, Eurofarma Laboratories, São Paulo, Brazil) and dimethyl sulfoxide (DMSO) were the positive and negative controls. The plates were incubated for $24 \mathrm{~h}$ at $37^{\circ} \mathrm{C}$ and then $10 \mu \mathrm{L}$ of $3-(4,5-$ dimethylthiazol-2-yl)-2,5-diphenyltetrazolium bromide (MTT) $\left(\right.$ Sigma $\left.^{\circ}\right)$ was added to each well. A blue color indicated that there were living cells (active metabolism), and a yellow color indicated the absence of living cells.

\section{Checkerboard dilution test}

The activity of $A$. cymbifera extracts supplemented with streptomycin against the four studied bacteria was assessed by the checkerboard dilution test, as described by Lee et al. (2012) and Kumar et al. (2012), with adaptations. Sequential dilutions of different proportions of the extract/streptomycin mixture were performed (with initial concentration of $50 \mathrm{mg} \mathrm{L}^{-1}$ in the first microplate's column) using nutrient broth (HiMedia Laboratories ${ }^{\circ}$, India) as the growth medium. After $24 \mathrm{~h}$ of incubation at $37^{\circ} \mathrm{C}$, the plates were read on a spectrophotometer (EMax Endpoint ${ }^{\circ}$ ), and the MIC was considered as the minimal concentration that demonstrated less than or equal to 10 percent of the control optical density or did not show any observable growth. The fractional inhibitory concentration index (FICI) was calculated using the equation:

$$
\mathrm{FICI}=\mathrm{FIC}_{\text {extract }}+\mathrm{FIC}_{\text {streptomycin }}
$$

with:

$$
\mathrm{FIC}_{\text {extract }}=\mathrm{MIC}_{\text {extract }+ \text { streptomycin }} / \mathrm{MIC}_{\text {extract }}
$$

and 
$\mathrm{FIC}_{\text {streptomycin }}=\mathrm{MIC}_{\text {extract+streptomycin }} / \mathrm{MIC}_{\text {streptomycin }}$

Values of FICI less than or equal to 0.50 were considered to be indicative of a synergic effect. Values ranging from 0.51 to 1.00 indicated an additive effect, values from 1.01 to 2.00 were considered as indifferent and values above 2.00 indicated an antagonist effect.

The interaction index (II) was used to describe the degree to which the extract induced an increase in the activity of streptomycin and to compare the different effects between the extracts. The II was determined using the formula:

$$
\mathrm{II}=\left(1 / \mathrm{FIC}_{\text {streptomycin }}\right)-1
$$

(See the derivation of the equation in Additional file 2).

\section{Assessment of cytotoxicity in mammalian cells}

MA104 cells (ATCC) (rhesus monkey kidney cells) were cultured in Dulbecco's Modified Eagle Medium (DMEM) $\left(\right.$ Sigma $\left.^{\circ}\right)$ supplemented with 6 percent of Fetal Bovine Serum (FBS) at $37^{\circ} \mathrm{C}$ in a 5 percent $\mathrm{CO}_{2}$ atmosphere in 96-well microplate until 95 percent confluence was reached. The wells were washed twice with phosphatebuffered saline (PBS) and $200 \mu \mathrm{L}$ of extracts from 250 to $1.95 \mathrm{mg} \mathrm{L}^{-1}$ in DMEM with 2 percent of FBS were added. After $48 \mathrm{~h}$ of incubation, the medium was discarded and $20 \mu \mathrm{L}$ of MTT was added to each well. After $1 \mathrm{~h}, 130 \mu \mathrm{L}$ of DMSO was added, and the UV/Vis absorbance was measured with a spectrophotometer to determine the concentration of the extract that killed 50 percent of cells (CC50) Twentyman and Luscombe, 1987.

\section{Statistical analysis}

All assays were performed in triplicate in three independent experiments. The mean $\pm \mathrm{SD}$ were used to describe the results. To analyze the data, descriptive statistics, analysis of variance (ANOVA) and non-linear regression were applied with 95 percent confidence intervals Skoog, 2007.

\section{Additional files}

Additional file 1: Effect of the interaction between streptomycin and ethanolic (EHE), dichloromethanic (EDI) and hexanic (EHE) extracts from A. cymbifera. This file shows a detailed table of the MIC of each mixture of streptomycin/extract and its respective FICs and FICI.

Additional file 2: Derivation of the interaction index (II) equation. This file shows the idea that led the authors to use a different method to calculate and define the interaction index (II). It also describes the II equation derivation in an easy to understand format (Straetemans et al. 2005; Tallarida 2002).

\section{Competing interests}

The authors declare that they have no competing interests.

\section{Authors' contributions}

WF carried out all of the assays as well as the statistical analysis and he was helped by SG in some of the procedures, such as preparation of the $A$. cymbifera extracts, and analyzing the data. JC conceived this study and designed and coordinated this study as well as guided WF and SG in the experiments. CLB, JMS and AH provided technical and intellectual support, participating in the results and methodological discussions. All authors helped to draft this article and read and approved the final manuscript.

\section{Acknowledgements}

The authors would like to acknowledge FAPEMIG and MEC/Sesu (Tutorial Education Program-PET) for fellowship support, Universidade Federal de São João Del-Rei for other support, Dra Daniela Leite Fabrino and Dr. Juliano Lemos Bicas, UFSJ, Ouro Branco, MG, Brazil, Dr. Rafael Russo Chagas, UFSJ, Divinopolis, MG, Brazil, Dr Sidney Augusto Vieira Filho, UFOP, Ouro Preto, MG, Brazil, Camila Magalhães Dias, Juliana Gomes Santana and Jéssica dos Santos Diniz (undergraduates), Ouro Branco, MG, Brazil for contributions.

\section{Author details}

'Programa de Educação Tutorial (PET-DPCFC), Universidade Federal de São João Del-Rei, Campus Alto Paraopeba, Ouro Branco, Minas Gerais, Brazil. ${ }^{2}$ Programa de Pós-graduação em Tecnologias para o desenvolvimento sustentável (PGTDS), Universidade Federal de São João Del-Rei, Campus Alto Paraopeba, Ouro Branco, Minas Gerais, Brazil. ${ }^{3}$ Departamento de Ciências Biológicas (DECBI), Universidade Federal de Ouro Preto, Ouro Preto, Minas Gerais, Brazil. ${ }^{4}$ Campus Centro Oeste Dona Lindu, Universidade Federal de São João del-Rei, Divinópolis, Minas Gerais, Brazil. ${ }^{5}$ Departamento de Química, Biotecnologia e Engenharia de Bioprocessos (DQBIO), Universidade Federal de São João Del-Rei, Campus Alto Paraopeba, Rodovia MG 443, Km 07, Congonhas/Ouro Branco, Ouro Branco, Minas Gerais CEP 36420-000, Brazil.

Received: 3 May 2013 Accepted: 22 August 2013

Published: 3 September 2013

\section{References}

Al-Masaudil SB, Day MJ, Russell AD (1991) Antimicrobial resistance and gene transfer in Staphylococcus aureus. J Appl Microbiol 70:279-290

Alviano DS, Alviano CS (2009) Plant extracts: search for new alternatives to treat microbial diseases. Curr Pharm Biotechnol 10:106-121

Alviano WS, Alviano DS, Diniz CG, Antoniolli AR, Alviano CS, Farias LM, Carvalho MAR, Souza MMG, Bolognese AM (2008) In vitro antioxidant potential of medicinal plant extracts and their activities against oral bacteria based on Brazilian folk medicine. Arch Oral Biol 53:545-552

Auwaerter PMD et al (2013) 2012-2013 Antibiotic Guidelines. Johns Hopkins Medicine., Available from: http://www.hopkinsmedicine.org/amp/guidelines/ Antimicrobial_Guidelines_2012-13.pdf. Accessed 12 Mar 2013

Carvalho CS, Reimão JQ, Tempone AG, Sartorelli P (2008) Diterpeno com atividade anti-Leishmania isolado de folhas de Aristolochia cymbifera (Aristolochiaceae). Paper presented at the 31a Reunião Anual da SBQ. Sociedade Brasileira de Química, Águas de Lindóia, 26 May 2008

Ceuppens S, Uyttendaele M, Hamelink S, Boon N, Wiele TV (2012) Inactivation of Bacillus cereus vegetative cells by gastric acid and bile during in vitro gastrointestinal transit. Gut Pathogens 3:4-11

Chen Y-Y, Chung Jing-G W, Hsiu-C BD-T, Kuen-Y W, Shung-T K, Chien-Y H, Tin-Y H, Chiang S-Y (2010) Aristolochic acid suppresses DNA repair and triggers oxidative DNA damage in human kidney proximal tubular cells. Oncol Rep 24:141-153

Chin Y-W, Balunas MJ, Chai HB, Kinghorn AD (2006) Drug discovery from natural sources. AAPS Journal 8:E239-E253

Cole EC, Addison RM, Rubino JR, Leese KE, Dulaney PD, Newell MS, Wilkins J, Gaber DJ, Wineinger T, Criger DA (2003) Investigation of antibiotic and antibacterial agent cross-resistance in target bacteria from homes of antibacterial product users and nonusers. J Appl Microbiol 95:664-676

European Committee on Antimicrobial Susceptibility Testing (2013) http://www. eucast.org. Accessed 12 Mar 2013

Hyeon J-Y, Gyung-Tae C, Sun-Hye B, Kyung-Sook K, Hyeon-Hee L, Soo-Jin K, SeEun J, Yeon-Ho K, Junyoung K (2013) A foodborne outbreak of Staphylococcus aureus associated with fried chicken in Republic of Korea. J Microbiol Biotechnol 23:85-87 
Jennison AV, Verma NK (2004) Shigella flexneri infection: pathogenesis and vaccine development. FEMS Microbiol Rev 28:43-58

Kumar SN, Siji JV, Nambisan B, Mohandas C (2012) Activity and synergistic antimicrobial activity between diketopiperazines against bacteria in vitro. Appl Biochem Biotechnol 168:2285-2296

Lee Y-S, Jang Kyeung-Ae C, Jeong-Dan (2012) Synergistic antibacterial effect between silibinin and antibiotics in oral bacteria. J Biomed Biotechnol 2012:1-7

Leitão GG, Kaplan MAC, Galeffi C (1992) epi-Populifolic acid from Aristolochia cymbifera. Phytochemistry 31:3277-3279

Lopes LMX, Bolzani VS (1988) Lignans and diterpenes of three Aristolochia species. Phytochemistry 27:2265-2268

Lopes LMX, Bolzani VS, Trevisan LMV (1987) Clerodane diterpenes from Aristolochia species. Phytochemistry 26:2781-2784

Luzzatto L, Apirion TD, Schlessinger D (1968) Mechanism of action of Streptomycin in E. coli: Interruption of the ribosome cycle at the initiation of protein synthesis. Proc Natl Acad Sci 60:873-880

Machado TB, Leal ICR, Kuster RM, Amaral ACF, Kokis V, Silva MG, Santos KRN (2005) Brazilian phytopharmaceuticals - evaluation against hospital bacteria. Phytoter Re 19:519-525

Mangeney N, Niel P, Paul G, Faubert E, Hue S, Dupeyron C, Louarn F, Leluan G (2000) A 5-year epidemiological study of extended-spectrum $\beta$-lactamase -producing Klebsiella pneumoniae isolates in a medium- and long-stay neurological unit. J Appl Microbiol 88:504-511

Martinez MC, Nortier J, Vereestraeten P, Vanherweghem JL (2002) Progression rate of Chinese herb nephropathy: impact of Aristolochia fangchi ingested dose. Nephrol Dial Transplant 17:408-412

Moran GJ, Abrahamian FM, Lovecchio F, Talan DA (2013) Acute bacterial skin infections: developments since the 2005 Infectious Diseases Society of America (IDSA) Guidelines. J Emerg Med 44:397-412

NCCLS (2003) Methods for Dilution Antimicrobial Susceptibility Tests for Bacteria That Grow Aerobically; Approved Standard- $6^{\text {th }}$ Edition., NCCLS document M7-A6. ISBN 1-56238-486-4

Newman DJ, Cragg GM, Snader KM (2000) The influence of natural products upon drug discovery. Nat Prod Rep 17:215-234

Nortier JL, Martinez MC, Schmeiser HH, Arlt VM, Bieler CA, Petein M, Depierreux MF, De Pauw L, Abramowicz D, Vereerstraeten P, Vanherweghem JL (2000) Urothelial carcinoma associated with the use of a Chinese herb. N Engl J Med 342:1686-1692

Reinhardt TA, Sacco RE, Nonnecke BJ, Lippolis JD (2013) Bovine milk proteome: quantitative changes in normal milk exosomes, milk fat globule membranes and whey proteomes resulting from Staphylococcus aureus mastitis. J Proteomics 82:141-154

Rios JL, Recio MC (2005) Medicinal plants and antimicrobial activity. J Ethnopharmacol 100:80-84

Sartoratto A, Machado AALM, Delarmelina C, Figueira GM, Duarte MCT, Rehder VLG (2004) Composition and antimicrobial activity of essential oils from aromatic plants used in Brazil. Bras J Microbiol 35:275-280

Sartorelli P, Carvalho CS, Reimão JQ, Lorenzi H, Tempone AG (2010) Antitrypanosomal activity of a diterpene and lignans isolated from Aristolochia cymbifera. Planta Med 76:1454-1456

Skoog DA (2007) Tratamento e avaliação estatística de dados. In: Skoog DA, West DM, Holler FJ, Crouch SR (eds) Fundamentos de Química Analítica, 8th edn. Thomson, São Paulo

Souza AB, Souz MGM, Moreira MA, Moreira MR, Furtado NAJC, Martins CHG, Bastos JK, Santos RA, Heleno VCG, Ambrosio SR, Veneziani RCS (2011) Antimicrobial evaluation of diterpenes from Copaifera langsdorffii oleoresin against periodontal anaerobic bacteria. Molecules 16:9611-9619

Straetemans R, O'Brien T, Wouters L, Van Dun J, Janicot M, Bijnens L, Burzykowski T, Aerts M (2005) Design and analysis of drug combination experiments. Biom J 47:299-308

Tallarida RJ (2002) The interaction index: a measure of drug synergism. Pain 98:163-168

Tenover FC (2006) Mechanisms of antimicrobial resistance in Bacteria. Am J Med 119:S3-S10

Turnbull PCB, Sirianni NM, LeBron Cl, Samaan MN, Sutton FN, Reyes AE, Peruski LF Jr (2004) MIC's of selected antibiotics for Bacillus anthracis, Bacillus cereus, Bacillus thuringiensis, and Bacillus mycoides from a range of clinical and environmental sources as determined by the Etest. J Clin Microbiol 42:3626-3634
Twentyman PR, Luscombe M (1987) A study of some variables in a tetrazolium dye (MTT) based assay for cell growth and chemosensitivity. Br J Cancer 56:279-285

Veiga VF Jr, Pinto AC, Maciel MAM (2005) Medicinal plants: safe cure? Quim Nova 28:519-528

Wu T-S, Damu AG, Su C-R, Kuo P-C (2004) Terpenoids of Aristolochia and their biological activities. Nat Prod Rep 21:594-624

doi:10.1186/2193-1801-2-430

Cite this article as: Silva et al: Combination of extracts from Aristolochia cymbifera with streptomycin as a potential antibacterial drug.

SpringerPlus 2013 2:430

\section{Submit your manuscript to a SpringerOpen ${ }^{\odot}$ journal and benefit from:}

- Convenient online submission

- Rigorous peer review

- Immediate publication on acceptance

- Open access: articles freely available online

High visibility within the field

- Retaining the copyright to your article

Submit your next manuscript at $\gg$ springeropen.com 